\title{
Characterization of Acidic Tuna Protease and Its Application for Extraction of Tilapia Collagen Hydrolysate
}

\author{
Patwarin Tohmadlae, Wanchai Worawattanamateekul, \\ and Jirapa Hinsui*
}

\begin{abstract}
Department of Fishery Products, Faculty of Fisheries, Kasetsart University, Bangkok 10900, Thailand
\end{abstract}

*Corresponding author.E-mail: jirapa_h@hotmail.com https://oi.org/10.12982/CMUJNS.2020.00014

Received: March 3, 2018

Revised: May 15, 2019

Accepted: July 1, 2019

\begin{abstract}
Thailand is a leading exporter of canned tuna globally. Many by-products are created during processing, including head, bone, blood and stomach. The stomach can serve as a promising source of pepsin, while collagen hydrolysate can be obtained as a new value-added product with high market value. The objectives of this study were to characterize pepsin from tuna stomachs and evaluate its application for extraction of collagen hydrolysate from tilapia skin. Pepsin from the stomachs of albacore tuna, skipjack tuna, and yellowfin tuna was characterized. Pepsin from all tuna species was extracted with phosphate buffer ( $\mathrm{pH} 7$ ) at $4^{\circ} \mathrm{C}$ for $3 \mathrm{~h}$ then mixed with $2 \mathrm{M}$ acetic acid at 1:1 (w/v) for 30 minutes. The characterization of crude enzyme was determined. The optimum $\mathrm{pH}$ of all tuna pepsin was 2 , and stable at pH2-3. Optimum temperature of all tuna pepsin was $50{ }^{\circ} \mathrm{C}$, and it was stable at 10-50 ${ }^{\circ} \mathrm{C}$. This enzyme responded to EDTA, urea, copper sulfate and magnesium sulfate. Albacore tuna (3.52 \pm 1.09 unit/ml), skipjack tuna $(3.42 \pm 1.008 \mathrm{unit} / \mathrm{ml})$, yellowfin tuna $(3.51 \pm 0.29 \mathrm{unit} / \mathrm{ml})$ and porcine pepsin $(3.96 \pm 0.00 \mathrm{unit} / \mathrm{ml})$ were applied for collagen hydrolysate extraction at $50{ }^{\circ} \mathrm{C}$ for 0-3 h. Degree of hydrolysis (\%DH) of yellowfin tuna pepsin was highest $(75.99 \pm 0.02 \%)$ at $50{ }^{\circ} \mathrm{C}$ for $1 \mathrm{~h}$. Collagen hydrolysate showed antioxidant properties (DPPH, ABTS and FRAP). Yellowfin tuna pepsin can be applied in food supplement production as well to commercial porcine pepsin.
\end{abstract}

Keyword: Protease, Tuna pepsin, Collagen hydrolysate, Fish skin, Tilapia skin 


\section{INTRODUCTION}

Thailand is the world's largest producer and exporter of canned tuna. The most commercially important tuna species for the Thai tuna industry is skipjack tuna, followed by yellowfin and albacore tuna, together accounting for over $80 \%$ of Thai frozen tuna imports (Thai customs, 2019; Thai Tuna Industry Association, 2019). Canned tuna processing creates 390,342 tons of by-product per year (Thai Tuna Industry Association, 2019):33\% heads, 8\% viscera, 16\% bone, 9\% blood and fish boiling water (Prasertsan and Choorit, 1988; Herpandi, 2011; Madhumita, 2011; Worawattanamateekul, 2013). Tuna viscera contain protein and protease, Protein hydrolysate from yellowfin and skipjack tuna viscera was autolysis (Detkamhaeng et al., 2016). Pepsin from albacore tuna, skipjack tuna and tongol tuna showed maximal activity at $\mathrm{pH} 2.0$ and $50{ }^{\circ} \mathrm{C}$ when hemoglobin was used as a substrate. When used for collagen extraction from the skin of threadfin bream for $12 \mathrm{~h}$, pepsin from skipjack tuna caused the degradation of alpha and beta components. (Nalinanon et al., 2008b). Pepsin 1 and 2 from the stomach of skipjack tuna was stable in the $\mathrm{pH}$ range of 2-5 and at temperatures up to $50{ }^{\circ} \mathrm{C}$. Both pepsins effectively hydrolyzed bovine serum albumin, egg white, natural actomyosin from brownstripe red snapper muscle and acidsolubilized collagen from arabesque greenling skin (Nalinanon et al., 2010b). Protein hydrolysate from the muscle of ornate threadfin bream produced by skipjack tuna pepsin is a promising source of functional peptides with antioxidant properties (Nalinanon et al., 2011). The objectives of this study were to characterize pepsin from tuna stomachs and evaluate its application for extraction of collagen hydrolysate from tilapia skin.

\section{MATERIALS AND METHODS}

\section{Materials}

Yellowfin tuna (Thunnus albacores) and skipjack tuna (Katsuwonus pelamis) stomachs were obtained from Pataya Food Industries Ltd. Albacore tuna (Thunnus alalunga) stomachs were obtained from Thai Union Group PCL., Samutsakorn, Thailand. The stomachs $(5 \mathrm{~kg})$ were packed in polyethylene bags and kept in ice with a stomach to ice ratio of 1:2(w/w). The materials were transported to the Department of Fishery Products, Kasetsart University, Bangkok within $2 \mathrm{~h}$. Tuna stomachs were prepared by cutting into small pieces and grinding, and then were placed in polyethylene bags ( $1 \mathrm{~kg}$ tuna stomach/bag) and stored at $-20{ }^{\circ} \mathrm{C}$ until further use.

Nile Tilapia (Oreochromis niloticus) skins were obtained from Grobest Marine Co., Ltd., Bangkok, Thailand. The skins $(10 \mathrm{~kg})$ were packed in polyethylene bags and kept in ice with a fish skin to ice ratio of $1: 2(\mathrm{w} / \mathrm{w})$. The material was transported to the Department of Fishery Products, Kasetsart University, Bangkok within $2 \mathrm{~h}$. Skins were prepared by trimming off remaining 
meat. The skins were then cut into small pieces $\left(1.0 \times 1.0 \mathrm{inch}^{2}\right)$ and placed in polyethylene bags $(1 \mathrm{~kg} \mathrm{skin} / \mathrm{bag})$ and stored at $-20{ }^{\circ} \mathrm{C}$ until use.

\section{Extraction and characterization of enzyme}

Protease extraction followed a modified method of Nalinanon et al. (2009). Tuna stomach tissue was homogenized with an extraction buffer $(\mathrm{pH} 7)(1: 3$ $(\mathrm{w} / \mathrm{v}))$ at $4{ }^{\circ} \mathrm{C}$ for $3 \mathrm{~h}$. The mixture was centrifuged at $10,000 \mathrm{xg}$ at $4{ }^{\circ} \mathrm{C}$ for 30 minutes. The supernatant was collected and activated with $2 \mathrm{M}$ acetic acid (1:1 $(\mathrm{w} / \mathrm{v}))$ at $4^{\circ} \mathrm{C}$ for 30 minutes and then filtered using two layers of cheesecloth. The characteristics of crude enzyme were analyzed.

Determination of protein concentration. Protein concentration of protease was determined according to Lowry et al. (1951) and Peterson (1997) using bovine serum albumin (BSA) as a standard in the range of $0-1 \mathrm{mg} / \mathrm{ml}$. The absorbance of the resulting solution was measured at $750 \mathrm{~nm}$ using a UV-1700 spectrophotometer (Shimadzu, Japan). The blank was prepared in the same manner, except that distilled water was used instead of the sample.

Determination of pepsin activity. Pepsin activity from tuna stomachs was determined according to Nalinanon et al. (2009) using hemoglobin as a substrate. The absorbance of the resulting solution was measured at $750 \mathrm{~nm}$ using a UV1700 spectrophotometer (Shimadzu, Japan). The blank was prepared in the same manner, except that distilled water was used instead of the sample. A standard curve was prepared using tyrosine in the range of $0-1 \mu \mathrm{M}$. Pepsin activity was then calculated using the following formula:

Activity $($ Unit $/ \mathrm{ml})=\left([\text { Protein }]_{\text {Sample }}-[\text { Protein }]_{\text {Control }}\right) /($ Time of the reaction (min) $x$ Volume of enzyme solution (ml))

Specific activity was then calculated using the following formula:

Specific activity (unit/mg protein) $=[$ Pepsin activity (unit $/ \mathrm{ml}) /$ Soluble protein $(\mathrm{mg} / \mathrm{ml})]$

Determination of characteristics of protease. Optimum and stable $\mathrm{pH}$, and optimum and stable temperature of crude enzyme were determined according to Nalinanon et al. (2010a) using $\mathrm{pH} 2-7$ and temperature of $10-70{ }^{\circ} \mathrm{C}$, respectively.

Determination of inhibition of protease. Inhibition of protease was determined according to Nalinanon et al. (2008a) using EDTA, urea, $\mathrm{CaCl}_{2}$, $\mathrm{CuSO}_{4}$ and $\mathrm{MgSO}_{4}$ as inhibitors.

SDS-polyacrylamide gel electrophoresis (SDS-PAGE). Protein patterns of enzyme solution were determined by sodium dodecyl sulfate polyacrylamide gel electrophoresis (SDS-PAGE), with $12.5 \%$ separating gel and 4\% stacking gel according to the method described by Laemmli (1970). Enzyme solution 
was prepared. Enzyme solution mixed with sample buffer $(0.5 \mathrm{M}$ Tris- $\mathrm{HCl}$, $\mathrm{pH} 6.8$ containing $10 \%$ SDS (w/v), glycerol, $0.5 \%$ bromophenol blue, 2-mercaptoethanol) at a ratio of $1: 1(\mathrm{v} / \mathrm{v})$. The mixtures were incubated at $90{ }^{\circ} \mathrm{C}$ for 30 minutes and centrifuged at $6,000 \mathrm{xg}$ for $30 \mathrm{~min}$ to remove insoluble debris. The loading volume of each sample was $10 \mu \mathrm{l}$ per well. Electrophoresis was performed at a constant voltage of $180 \mathrm{~V}$ by using Mini-Protein ${ }^{\circledR} \mathrm{II}$ Electrophoresis cell (Bio-Rad Laboratories Ltd, Thailand). After electrophoresis, the gel was stained with $0.1 \%$ (w/v) Coomassie blue R-250 in $40 \%$ (v/v) methanol, $10 \%(\mathrm{v} / \mathrm{v})$ acetic acid and $50 \%(\mathrm{v} / \mathrm{v})$ water, and then de-stained with $40 \%(\mathrm{v} / \mathrm{v})$ methanol, $10 \%(\mathrm{v} / \mathrm{v})$ acetic acid and 50\% (v/v) water. Precision plus protein standard (New England BioLabs Inc., USA) was used to estimate the molecular weight of protein.

\section{Preparation of Tilapia skin}

Tilapia skin was prepared according to Tohmadlae et al. (2019). To remove blood, mucus, soluble proteins, lipids, non-collagen substances such as elastin, albumin, mucopolysaccharide and fishy odor.

\section{Collagen hydrolysate extraction}

Collagen hydrolysate extraction from tilapia skin with acidic protease from tuna stomach (albacore tuna, skipjack tuna and yellowfin tuna) was compared with commercial porcine pepsin (Sigma-Aldrich, USA). All enzymes had the same activity value. Tilapia skin was extracted by enzyme solution $(1: 10(\mathrm{w} / \mathrm{v}))$ at $50{ }^{\circ} \mathrm{C}$ for $0-3 \mathrm{~h}$ and then enzyme activity was stopped by heating at $100{ }^{\circ} \mathrm{C}$ for 15 minutes. The mixture was centrifuged at $10,000 \mathrm{xg}$ at $4{ }^{\circ} \mathrm{C}$ for 30 minutes. The supernatant was collected for characterization of collagen hydrolysate.

\section{Determination of degree of hydrolysis (DH)}

The DH of the collagen hydrolysate was determined according to the method of Nielsen (2010). Degree of hydrolysis was then calculated using the following formula: material

DH $(\%)=$ Total nitrogen in collagen hydrolysate $\mathrm{x} 100 /$ Total nitrogen in

\section{Yield of extracted collagen hydrolysate}

Yield of extracted collagen hydrolysate was calculated from the formula:

Yield $(\%)=$ dried weight of collagen hydrolysate $\mathrm{x}$ 100/wet weight of skin

\section{Determination of amino acid}

Amino acid composition of the tilapia collagen hydrolysate was determined by an in-house method based on the Official Journal of the European Communities, L257/16 (1983). After hydrolysis, the sample was dried (vacuum 
centrifuge) and resolved in $500 \mu 1$ sodium-acetate buffer $\mathrm{pH}$ 2.2. The amino acids were separated by ion exchange chromatography, in which $20 \mu \mathrm{l}$ of the sample was loaded onto an amino acid analyzer LC 3000 (Eppendoef-Biotronik, Germany) equipped with a polymer cation exchange column $(125 \times 4 \mathrm{~mm})$, followed by a post-column derivatization with phenyl isothiocyanate at $125{ }^{\circ} \mathrm{C}$. The detection was carried out at $570 \mathrm{~nm}$ and $440 \mathrm{~nm}$ for proline. This method determined the amino acid content of tilapia collagen hydrolysate.

\section{Determination of antioxidant activities}

DPPH and ABTS radical scavenging activity and FRAP of the collagen hydrolysate was determined following methods modified from Wu et al. (2003), Sukkwei et al. (2010), Aleman et al. (2011), Ketnawa and Liceaga (2017), respectively using trolox in methanol as a positive control. A standard curve was prepared using trolox in the range of 10-50, 25.71-60 and 0-850 $\mu \mathrm{M}$, respectively. The absorbance of the resulting solution was measured at 517, 734 and $595 \mathrm{~nm}$, respectively, using a UV-1700 spectrophotometer (Shimadzu, Japan). Whereas $0.15 \mathrm{mM}$ DPPH in Ethanol, $7 \mathrm{mM}$ ABTS in $2.45 \mathrm{mM}$ Potassium persulfate. Metal chelating activity of the collagen hydrolysate was determined following aprotocol modified from Boyer and Cleary (1987) using urea, $\mathrm{CuSO}_{4}, \mathrm{CaCl}_{2}, \mathrm{MgSO}_{4}$ and EDTA as a positive control. A standard curve was prepared using EDTA in the range of $0-150 \mu \mathrm{M}$. The absorbance of the resulting solution was measured at $562 \mathrm{~nm}$ using a UV-1700 spectrophotometer (Shimadzu, Japan). The blank used was distilled water instead of the sample.

\section{Statistical analysis}

All experiments were run in triplicate with completely randomized design (CRD). Data were subjected to one-way analysis of variance (ANOVA) and mean comparisons were carried out using Duncan's multiple range test. Statistical tests were done using the statistic operating system. Differences between means were tested by Duncan's multiple range test. The data were presented as mean \pm standard deviation. A probability value of $P<0.05$ was considered statistically significant.

\section{RESULTS AND DISCUSSION}

Protease activity of albacore, skipjack and yellowfin tuna stomachs was $3.52 \pm 1.09,3.42 \pm 1.008$ and $3.51 \pm 0.29 \mathrm{unit} / \mathrm{ml}$, respectively. Specific activity for the same species was $0.1129 \pm 0.17,0.0983 \pm 0.61$ and $0.1021 \pm 0.74 \mathrm{unit} / \mathrm{mg}$ protein, respectively. Activity of the commercial porcine pepsin $(3.96 \pm 0.00$ unit/ml) was similar to tuna protease.

\section{pH optimum and stability}

Protease from tuna stomachs (albacore, skipjack and yellowfin tuna) and commercial enzyme (porcine pepsin) showed highest activity in $\mathrm{pH}$ range 2-4, 
while activity decreased from $\mathrm{pH}$ 5-7. In $\mathrm{pH}$ range 6-7 enzyme activity was less than $80 \%$. Therefore, $\mathrm{pH}$ optimum of protease was 2, as shown in Figure 1.

The $\mathrm{pH}$ stability curves for porcine pepsin and protease from the three species of tuna showed that the enzymes were stable within $\mathrm{pH}$ range 2-3, but when $\mathrm{pH}$ increased beyond 3, stability sharply decreased (Figure 2).

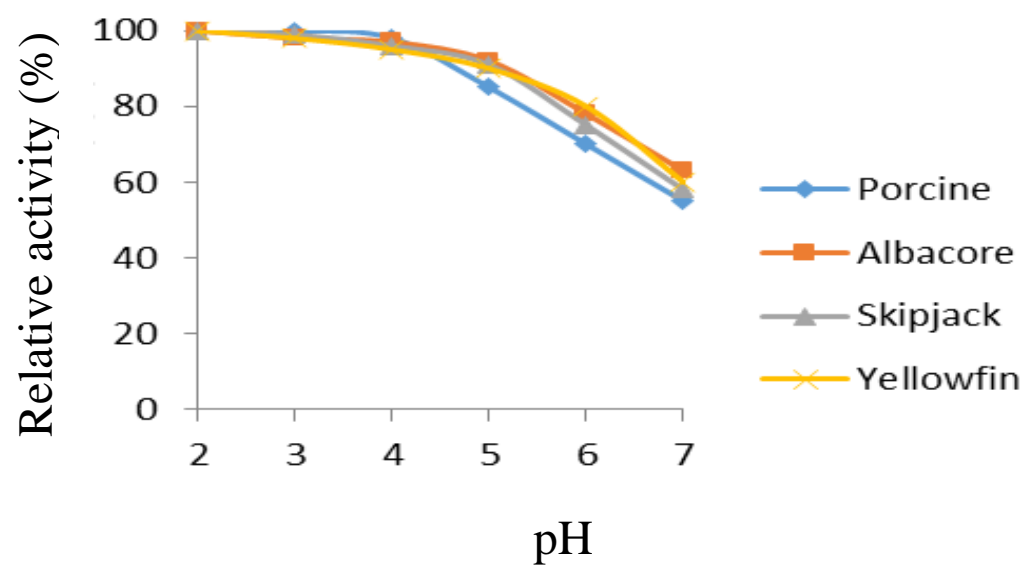

Figure 1. pH stability curve for porcine pepsin and protease from albacore, skipjack, and yellowfin tuna stomachs. Values presented as mean \pm SD from triplicate determinations.

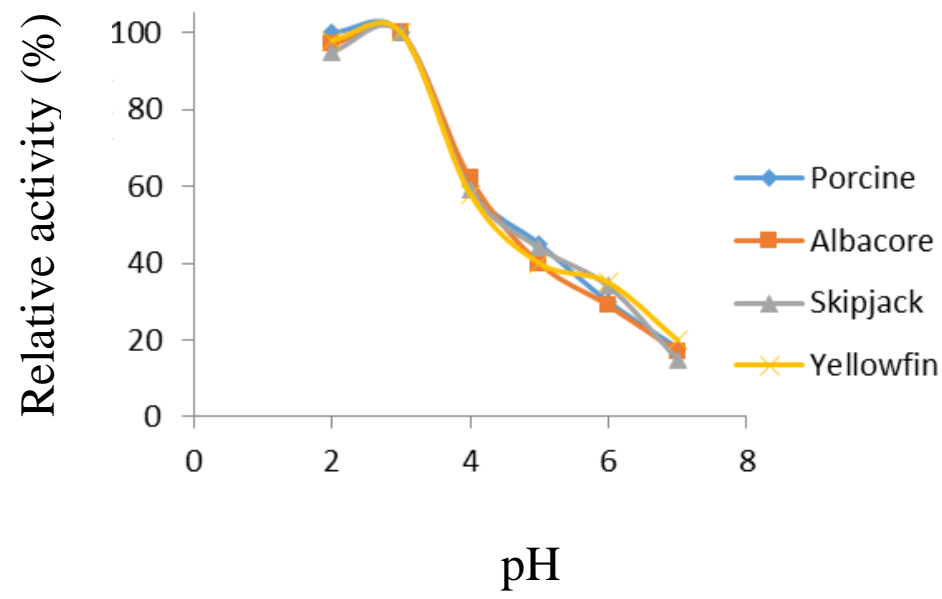

Figure 2. pH stability curve for porcine pepsin and protease from albacore, skipjack, and yellowfin tuna stomachs. Values presented as mean \pm SD from triplicate determinations.

\section{Temperature optimum and stability}

Enzyme activity increased with increasing temperature, from $10{ }^{\circ} \mathrm{C}$ to $50{ }^{\circ} \mathrm{C}$, followed by a sharp decrease at higher temperatures. Optimum temperature for protease activity was thus $50^{\circ} \mathrm{C}$, as shown in Figure 3 . 
Enzymes remained stable over the temperature range of $10-50{ }^{\circ} \mathrm{C}$ (Figure 4). Higher temperatures likely caused protein denaturing and loss of function.

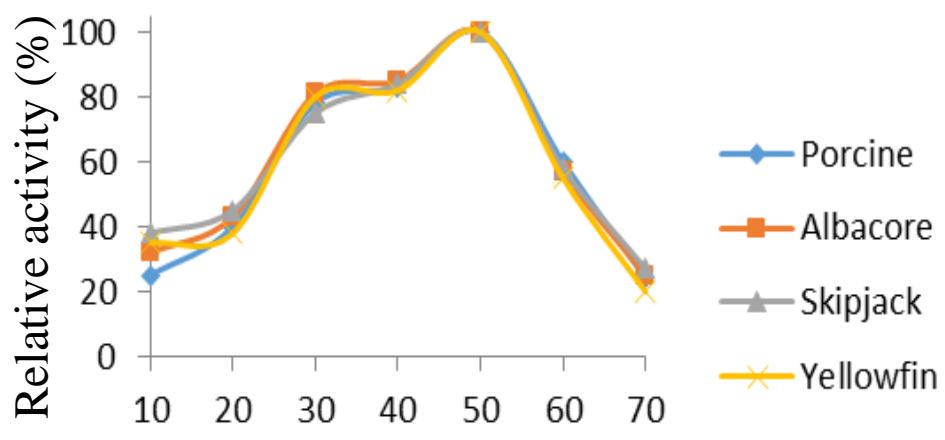

Temperature $\left({ }^{\circ} \mathrm{C}\right)$

Figure 3. Temperature activity curve for porcine pepsin and protease from albacore, skipjack, and yellowfin tuna stomachs. Values presented as mean \pm SD from triplicate determinations.

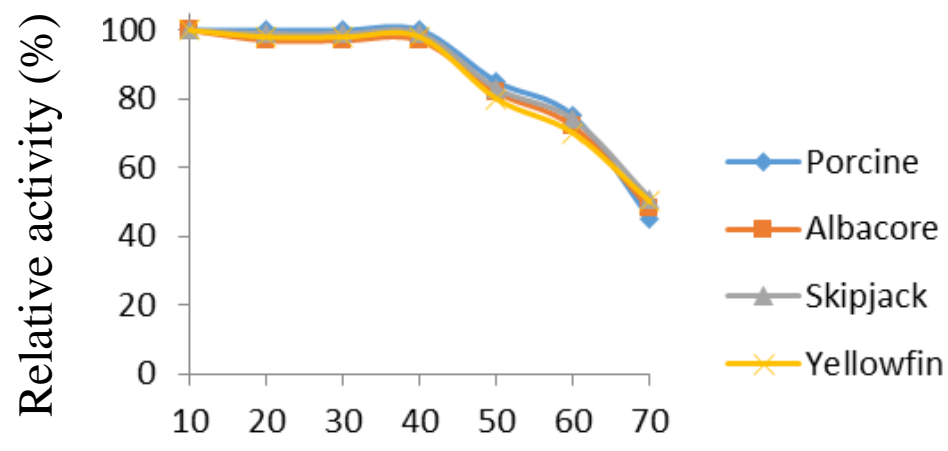

Temperature $\left({ }^{\circ} \mathrm{C}\right)$

Figure 4. Temperature stability curve for porcine pepsin and protease from albacore, skipjack, and yellowfin tuna stomachs. Values presented as mean \pm SD from triplicate determinations.

Optimum $\mathrm{pH}$ was 2 for all protease samples, and they were stable at a $\mathrm{pH}$ range of 2-3. Optimum temperature was $50{ }^{\circ} \mathrm{C}$ for all samples, and they were stable over the range of $10-50{ }^{\circ} \mathrm{C}$. These results concur with those found for protease activity from skipjack and albacore tuna stomachs, where optimum activity was at $\mathrm{pH} 2$ and temperature of $50{ }^{\circ} \mathrm{C}$ (Sathivel et al., 2003; Tanji et al., 2007; Nalinanon et al., 2008a; Nalinanon et al., 2010a; Zhoa et al., 2011). These optimum conditions were applied in the extraction of collagen hydrolysate from tilapia skin. 


\section{Inhibition of enzyme}

Enzyme activity from tuna protease and porcine pepsin was inhibited by all chemicals tested, as shown in Figure 5. EDTA can react with transition-metal ions, which are components of these enzymes. When reacting, it acts as a chelating substrate for the enzyme, so that the enzyme activity is reduced (Zhoa et al., 2011). Urea is a chemotropic agent that can cause proteins to denature by destroying the hydrogen bonds in the polypeptide and between the water solvent and the protein. Unfolding of the enzyme causes loss of enzyme function and the observed decrease in activity (Prasad et al., 2016).

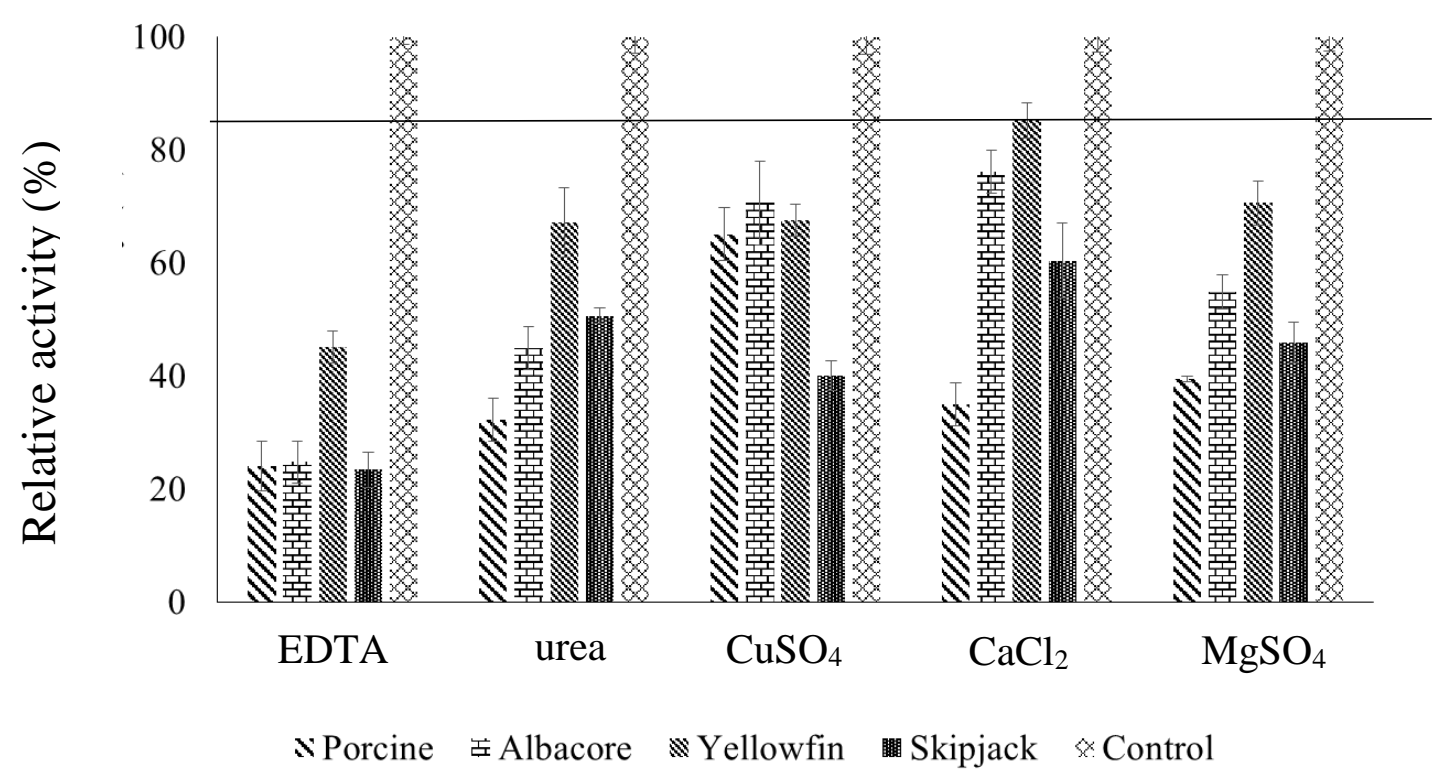

Figure 5. Inhibition by EDTA, urea, $\mathrm{CuSO}_{4}, \mathrm{CaCl}_{2}$ and $\mathrm{MgSO}_{4}$ of four enzymes (porcine pepsin and protease from albacore, skipjack, and yellowfin tuna stomachs) and a negative control (water). Values presented as mean \pm SD from triplicate determinations.

Chemicals containing metal ions such as $\mathrm{CuSO}_{4}, \mathrm{CaCl}_{2}$ and $\mathrm{MgSO}_{4}$ had effects on enzyme activity. Metal ions act as enzyme cofactors that accelerate the electron transmission process in the respiration chain, which leads to the proton pump from the inner wall of mitochondria and a build-up of ATP. Cyanide capture results in the cofactor being unable to send and receive electrons, and the ATP formation is stopped. This is classified as a non-invasive enzyme inhibition. Of the metals tested in this study, only $\mathrm{CaCl}_{2}$ did not inhibit the enzyme activity from yellowfin tuna stomach. Because the cofactor could still send and receive electrons, ATP continued to be produced

EDTA, urea, $\mathrm{CuSO}_{4}, \mathrm{CaCl}_{2}$ and $\mathrm{MgSO}_{4}$ can inhibit the activity of all enzymes (except $\mathrm{CaCl}_{2}$ in yellowfin tuna protease). Therefore, care should be 
taken not to allow these substances to contaminate reactions that involve these enzymes.

\section{SDS-polyacrylamide gel electrophoresis (SDS-PAGE)}

Protein patterns of protease were shown in Figure 6. All crude protease showed a similar pattern of molecular weight in range from 34.6 to $42.7 \mathrm{kDa}$. Acid proteases from tuna stomach with molecular weight in range from 30 to 40 $\mathrm{kDa}$ (Nalinanon et al., 2008b; Nalinanon et al., 2010a). The Mw of protease from albacore tuna was similar to those from polar cod (Arunchalam and Haard, 1985), North Pacific bluefin tuna (Tanji et al., 1988), smooth hound (Bougatef et al., 2008) and stomach of albacore tuna (Nalinanon et al., 2010a) which had MW ranging from 32 to $38 \mathrm{kDa}$ and acidic protease from skipjack tuna was similar to those from orange roughy (Hoplostethus atlanticus) stomach with molecular weight of $34.5 \mathrm{KDa}$ (Xu et al., 1996). In addition, many other protein bands were found because of the crude enzyme that has not been purified.

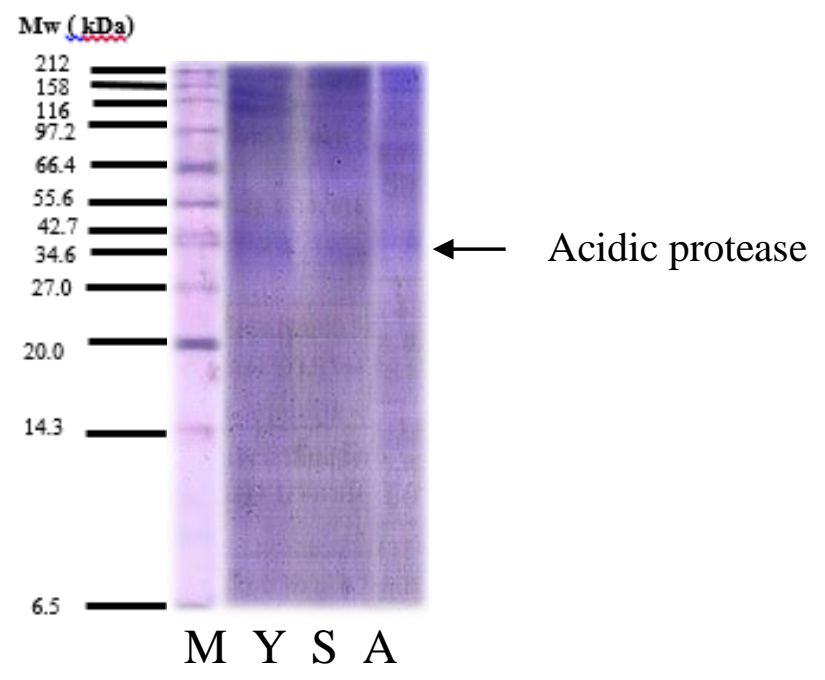

Figure 6. Protein $\mathrm{Mw}$ distributions of protease from yellowfin, skipjack, and albacore tuna stomachs. $\mathrm{M}=$ Protein Marker, $\mathrm{Y}=$ Yellowfin protease, $\mathrm{S}=$ Skipjack protease and $\mathrm{A}=$ Albacore protease.

\section{Degree of hydrolysis of tuna protease}

Results of tilapia skin hydrolysis with protease from tuna stomachs (albacore, skipjack, and yellowfin tuna) and commercial enzyme are displayed in Figure 7. Degree of hydrolysis (DH) increased from $0 \mathrm{~h}$ to $1 \mathrm{~h}$ of extraction (digestion) time. Increasing the extraction time to $2 \mathrm{~h}$ and $3 \mathrm{~h}$ did not significantly increase hydrolysis. Enzymes extracted from tuna stomachs gave a higher degree of hydrolysis than commercial enzyme. Enzyme extracted from skipjack tuna stomach had the highest DH $(33.41 \pm 0.72 \%)$, with optimum conditions of $50{ }^{\circ} \mathrm{C}$ and $1 \mathrm{~h}$ of extraction time. 


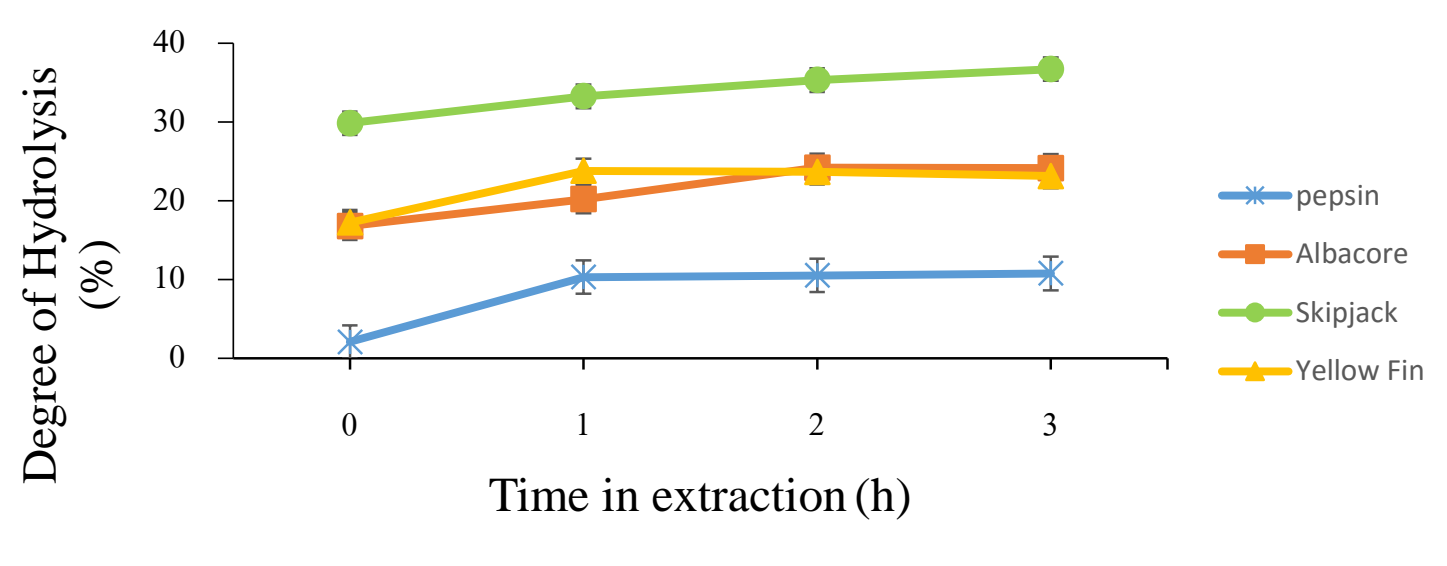

Figure 7. Degree of hydrolysis of tilapia skin by four enzymes (porcine pepsin and protease from albacore, skipjack, and yellowfin tuna stomachs) at different treatment times. Values presented as mean \pm SD from triplicate determinations.

\section{Amino acid content and antioxidant activity of collagen hydrolysate}

Table 1 shows the collagen hydrolysate yields for different enzyme type. The collagen hydrolysate yield varied from $47.00 \pm 0.89 \%$ to $95.42 \pm 0.68 \%$. In terms of difference enzyme type. It's not have effect to yield of collagen hydrolysate but commercial enzyme (porcine pepsin) has lowest yield of collagen hydrolysate.

Antioxidant activity of proteins and peptides does not depend on only one mechanism because proteins contain various amino acids with different antioxidant properties. Some antioxidant components are more effective as radical scavengers or lipid peroxidation inhibitors, whereas others are metalchelating or reducing (Aleman et al., 2011; Barzideh et al., 2014).

Amino acid content and antioxidant properties of tilapia collagen hydrolysate extracted by tuna protease $(\mathrm{TCH})$ and porcine pepsin $(\mathrm{PCH})$ were shown in Table 1 and 2, respectively. Tuna protease-extracted collagen hydrolysate (TCH) had high DPPH and ABTS scavenging properties, FRAP and ion ferrous chelating. Values were similar for porcine pepsin-extracted hydrolysate $(\mathrm{PCH})$.Values also correspond with antioxidant properties of gelatin hydrolysate from bigeye snapper skin (Phanturat et al., 2010) and walking catfish skin (Ketnawa et al., 2017). 
Table 1. Yield and antioxidant activity of collagen hydrolysate extracted from tilapia skin by four enzymes (porcine pepsin and protease from albacore, skipjack, and yellowfin tuna stomachs).

\begin{tabular}{|c|c|c|c|c|c|}
\hline Enzyme & Yield $(\%)^{*}$ & $\begin{array}{c}\text { DPPH }^{*} \\
(\mu \mathrm{mol} \text { TE/g } \\
\text { protein })\end{array}$ & $\begin{array}{c}\text { ABTS }^{*} \\
(\mu \mathrm{mol} \text { TE/g } \\
\text { protein })\end{array}$ & $\begin{array}{c}\text { FRAP }^{*} \\
(\mu \mathrm{mol} \text { TE/g } \\
\text { protein })\end{array}$ & $\begin{array}{c}\text { Chelating* } \\
\text { (mM EDTA/g } \\
\text { protein) }\end{array}$ \\
\hline $\mathrm{P}$ & $47.00 \pm 0.89^{\mathrm{b}}$ & $416.58 \pm 101.49^{c}$ & $3,472.90 \pm 846.0^{\mathrm{a}}$ & $5,635.09 \pm 1,438.6^{a}$ & $558.51 \pm 320.37^{a}$ \\
\hline YF & $75.99 \pm 0.02^{\mathrm{a}}$ & $535.27 \pm 64.98^{\mathrm{a}}$ & $1,483.79 \pm 108.1^{b}$ & $5,627.62 \pm 422.27^{\mathrm{a}}$ & $179.79 \pm 38.36^{\mathrm{b}}$ \\
\hline SJ & $95.42 \pm 0.68^{\mathrm{a}}$ & $491.27 \pm 20.34^{\mathrm{b}}$ & $1,891.03 \pm 78.2^{b}$ & $6,848.51 \pm 119.00^{\mathrm{a}}$ & $294.40 \pm 6.46^{\mathrm{b}}$ \\
\hline $\mathrm{AL}$ & $96.38 \pm 0.72^{\mathrm{a}}$ & $590.09 \pm 44.93^{\mathrm{a}}$ & $2,091.00 \pm 159.2^{b}$ & $2,819.62 \pm 297.55^{b}$ & $129.41 \pm 10.40^{\mathrm{b}}$ \\
\hline
\end{tabular}

Note: ${ }^{*}$ Values presented as mean \pm SD from triplicate determinations. ${ }^{\text {a-d }}$ Different letters in the same column indicate significant difference $(P<0.05) . P=$ porcine pepsin, $\mathrm{YF}=$ yellowfin tuna, $\mathrm{SJ}=$ skipjack tuna, $\mathrm{AL}=$ albacore tuna.

ABTS was significantly higher than DPPH for collagen hydrolysates extracted using all four enzymes in this study $(P<0.05)$. Due to ABTS is an active radical that reacts with peptide that has antioxidant properties and ABTS is a free radical that reacts in a water-soluble system. Therefore, tilapia collagen hydrolysate can inhibit ABTS scavenging properties better than DPPH scavenging properties. DPPH is a stable free radical and accepts an electron or hydrogen radical to become a stable diamagnetic molecule. DPPH is often used to evaluate the antioxidant activity (Qian et al., 2008). Tilapia collagen hydrolysates possibly hydrogen donors and could react with free radicals to convert them to more stable products and terminate the radical chain reaction. The pre-formed radical monocation of ABTS ${ }^{+}$is generated by oxidation of ABTS with potassium persulphate and is reduced in the presence of hydrogendonating antioxidants and of chain breaking antioxidants (Binsan et al., 2008). In addition, amino acids found in collagen hydrolysate: aspartic, glutamic, glycine, alanine, proline, valine, leucine, isoleucine, lysine and phenylalanine. These amino acids affect the antioxidant efficiency. Many amino acids have the effect of giving $\mathrm{H}^{+}$and $\mathrm{e}^{-}$and have an effect on $\mathrm{e}^{-}$receptors, as well as the ability to hold metals (Kunst, 2003; Atmaca, 2004).

FRAP of collagen hydrolysates showed differences among enzyme treatments $(P<0.05)$. The antioxidant potential of collagen hydrolysates was estimated from their ability to reduce the TPTZ-Fe (III) complex to the TPTZFe (II) complex (Binsan et al., 2008). From these results, collagen hydrolysates prepared with protease from tuna stomach (skipjack and yellowfin tuna) and commercial enzyme had the pronounced effect of donating electrons that led to the retardation of propagation of lipid oxidation (Binsan et al., 2008). 
An enhanced metal ion binding occurring due to the cleavage of peptides leading to an increased concentration of the carboxylic groups and the amino groups of the peptides (Liu et al., 2010). However, the shorter chain of peptides might lose their ability to form the complex with $\mathrm{Fe}^{2+}$ (Khantaphant et al., 2011).

Differences in DPPH, ABTS, FRAP and ferrous chelating between collagen hydrolysates prepared using different enzymes possibly resulted from existing differences. The antioxidant ability of protein hydrolysate depends on the source of initial protein, type of enzyme, peptide size, types of amino acids found in raw materials and ability to hydrolysis enzyme (Venuste et al., 2013).

Table 2. Amino acid content of collagen hydrolysate extracted from tilapia skin by four enzymes (porcine pepsin and protease from albacore, skipjack, and yellowfin tuna stomachs).

\begin{tabular}{|c|c|c|c|c|}
\hline \multirow{2}{*}{ Amino acid } & \multicolumn{4}{|c|}{ Amino acid content (mg/ 100 g protein) } \\
\hline & Porcine & Albacore & Skipjack & Yellowfin \\
\hline \multicolumn{5}{|l|}{ Hydrophobic amino acid } \\
\hline Isoleucine & - & 21.96 & 44.40 & 28.54 \\
\hline Leucine & - & 36.65 & 76.47 & 48.71 \\
\hline Methionine & - & - & - & - \\
\hline Phenylalanine & - & $<40.00$ & 41.63 & $<40.00$ \\
\hline Valine & - & 44.62 & 76.64 & 41.09 \\
\hline Alanine & $<30.00$ & 49.94 & 81.00 & 59.98 \\
\hline Proline & $<40.00$ & 51.10 & 74.79 & 62.46 \\
\hline \multicolumn{5}{|l|}{ Basic amino acid } \\
\hline Lysine & $<20.00$ & 34.46 & 78.95 & 53.21 \\
\hline Arginine & - & $<50.00$ & 76.82 & 57.65 \\
\hline Histidine & - & $<20.00$ & 36.74 & 29.40 \\
\hline \multicolumn{5}{|l|}{ Polar amino acid } \\
\hline Tyrosine & - & - & $<50.00$ & $<50.00$ \\
\hline Threonine & - & $<40.00$ & 53.60 & $<40.00$ \\
\hline Glycine & 58.62 & 82.49 & 113.42 & 95.61 \\
\hline Serine & - & $<40.00$ & 58.95 & $<40.00$ \\
\hline Cysteine & - & - & - & - \\
\hline Aspartic acid & 27.56 & 56.50 & 106.90 & 72.26 \\
\hline Glutamic acid & - & 82.51 & 154.07 & 102.50 \\
\hline
\end{tabular}

\section{CONCLUSION}

Optimum $\mathrm{pH}$ and stable $\mathrm{pH}$ of acidic protease from three species of tuna stomachs were 2 and 2-3, respectively, while optimum temperature and stable temperature were $50{ }^{\circ} \mathrm{C}$ and $10-50{ }^{\circ} \mathrm{C}$, respectively. When these enzymes were used to extract collagen hydrolysate, protease extracted from yellowfin tuna 
stomachs had the highest degree of hydrolysis of protein at $50{ }^{\circ} \mathrm{C}$ for $1 \mathrm{~h}$, and gave high yield and antioxidant properties. Tilapia protein hydrolysate is as effective as commercial porcine pepsin, and can applied in food supplement production.

\section{REFERENCES}

Aleman, A., Gimenez, B., Montero, P., and Gomez-Guillen, M.C. 2011. Antioxidant activity of several marine skin gelatin. LWT-Food Science and Technology. 44(2): 407-413. https://doi.org/10.1016.j.lwt.2010.09.003

Arunchalam, K., and Haard, N. F. 1985. Isolation and characterization of pepsin from polar cod (Boreogadus saida). Comparative Biochemistry and Physiology. 80B(3): 467-474. https://doi.org/10.1016/0305-0491(85) 90274-3

Atmaca, G. 2004. Antioxidant effects of sulfur-containing amino acids. Yonsei Medical. 45(5): 776-788. https://doi.org/10.3349/ymj.2004.45. 5.776

Barzideh, Z., Latiff, A.A., Gan, C.Y., Abedin, Z., and Alias, A.K. 2014. ACE inhibitory and antioxidant activities of collagen hydrolysates from the ribbonjellyfish (Chrysaora sp.). Food Technology and Biotechnology. 52(4): 495-504. https://doi.org/10.17113/ftb.52.04.14.3641

Binsan, W., Benjakul, S., Visessanguan, W., Roytrakul, S., Tanaka, M., and Kishimura, H. 2008. Antioxidative activity of Mungoong, an extract paste, from thecephalothorax of white shrimp (Litopenaeus vannamei). Food Chemistry. 106(1): 185-193. https://doi.org/10.1016/j.foodchem. 2007.05.065

Bougatef, A., Balti, R., Zaied, S. B., Souissi, N., and Nasri, M. 2008. Pepsinogen and pepsin from the stomach of smooth hound (Mustelus mustelus): purification, characterization and amino acid terminal sequences. Food Chemistry. 107(2): 777-784. https://doi.org/10.1016/j.foodchem.2007. 08.077

Boyer, R.F., and Cleary, C.J. 1987. Superoxide ion as a primary reductant in ascorbate-mediated ferritin iron release. Free Radical Biological Medics. 3: 389-395. https://doi.org/10.1016/0891-5849(87)90017-7

Detkamhaeng, N., Worawattanamateekul, W., and Hinsui, J. 2016. Production of protein hydrolysate from Yellowfin (Thunnus albacares) and Skipjack Tuna (Katsuwonous pelamis) viscera. Kasetsart University Fisheries Research Bulletin. 40(2): 51-67.

Herpandi, N.H., Rosma, A., and Nadiah, W.A.W. 2011. The tuna fishing industry: a new outlook on fish protein hydrolysate. Comprehensive Reviews in Food Science and Food Safety. 10: 195-207. https://doi.org/ 10.1111/j.1541-4337.2011.00155.x 
Ketnawa, S., and Liceaga, A.M. 2017. Effect of microwave treatment on antioxidant activity and antigenicity of fish frame protein hydrolysates. Food bioprocess Technology. 10(3): 582-591. https://doi.org/10.1007/ s11947-016-1841-8

Ketnawa, S., Benjakul, S., Martinez-Alvarez, O., and Rawdkuen, S. 2017. Fish skin gelatin hydrolysates produced by visceral peptidase and bovine trypsin: bioactivity and stability. Food Chemistry. 215: 383-390. https:// doi.org/10.1016/j.foodchem.2016.07.145

Khantaphant, S., Benjakul, S., and Kishimura, H. 2011. Antioxidative and ACE inhibitory activities of protein hydrolysates from the muscle of brown stripe red snapper prepared using pyloric caeca and commercial proteases. Process Biochemistry. 46(1): 318-327. https://doi.org/10.1016/ j.procbio.2010.09.005

Kunst, T. 2003. Protein modification in optimize functionality: protein hydrolysates. In: Whitaker J., Voragen A., and Wong D., editors. Handbook of food enzymology. New York: Marcel Dekker.

Laemmli, U.K. 1970. Cleavage of structural proteins during assembly of head of Bacteriophage T4. Nature. 277: 680-685. https://doi.org/10.1038/227 $680 \mathrm{a} 0$

Liu, Q., Kong, B., Xiong, X.L., and Xia, X. 2010. Antioxidant activity and functional properties of porcine plasma protein hydrolysate as influenced by the degree of hydrolysis. Food Chemistry. 118(2): 403-410. https://doi.org/10.1016/j.foodchem.2009.05.013

Lowry, O.H., Rosebrough, N.J., Farr, A.L., and Randall, R.J. 1951. Protein measurement with the folin phenol reagent. Journal of Biological Chemistry. 193: 265-275.

Madhumita, O. 2011. Corporate social responsibility. Oxford higher Education. Oxford University Press. pp. 1-57.

Nalinanon, S., Benjakul, S., Visessanguan, W., and Kishimura, H. 2008a. Improvement of gelatin extraction from bigeye snapper skin using pepsinaided process in combination with protease inhibitor. Food Hydrocolloids. 22(4): 615-622. https://doi.org/10.1016/j.foodhyd.2007.01.012

Nalinanon, S., Benjakul, S., Visessanguan, W., and Kishimura, H. 2008b. Tuna pepsin: characteristics and its use for collagen extraction from the skin of threadfin bream (Nemipterus spp.). Journal of Food Science. 73(5): 413419. https://doi.org/10.1111/j.1750-3841.2008.00777.x

Nalinanon, S., Benjakul, S., Kishimura, H., and Shahidi, F. 2011. Functionalities and antioxidant properties of protein hydrolysates from the muscle of ornate threadfin bream treated with pepsin from skipjack tuna. Food Chemistry. 124: 1354-1362. https://doi.org/10.1016/j.foodchem.2010. 07.089 
Nalinanon, S., Benjakul, S., Visessanguan, W., and Kishimura, H. 2009. Partitioning of protease form stomach of albacore tuna (Thunnus alalunga) by aqueous two-phase systems. Proceeding Biochemistry. 44: 471-476. https://doi.org/10.1016/j.procbio.2008.12.018

Nalinanon, S., Benjakul, S., and Kishimura, H. 2010a. Biochemical properties of pepsinogen and pepsin from the stomach of albacore tuna (Thunnus alalunga). Food Chemistry. 121(1): 49-55. https://doi.org/10.1016/ j.foodchem.2009.11.089

Nalinanon, S., Benjakul, S., and Kishimura, H. 2010b. Purification and biochemical properties of pepsins from the stomach of skipjack tuna (Katsuwonus polamis). European Food Research and Technology. 231(2): 259-269. https://doi.org/10.1007/s00217-010-1275-x

Nielsen, S.S. 2010. Food analysis laboratory: food science text series. $2^{\text {nd }}$ ed. London: Springer.

Official Journal of the European Communities, L 257. 1983. 26: 0014-0028.

Peterson, G.L. 1997. A simplification of the protein assay method of Lowry et al. which is more generally applicable. Analytical Biochemistry. 83(2): 346-356. https://doi.org/10.1016/0003-2697(77)90043-4

Phanturat, P., Benjakul, S., Visessanguan, W., and Roytrakul, S. 2010. Use of poloric caeca extract from bigeye snapper (Priacanthus macracanthus) for the production of gelatin hydrolysate with antioxidative activity. LWT-Food Science and Technology. 43: 86-97. https://doi.org/10.1016/ j.lwt.2009.06.010

Prasad, S., Negi, V.S., Laha, J.K., and Roy, I. 2016. Differential effect of a chemical denaturant on activity and stability of a serine protease in nonaqueous media. Journal of Molecular Catalysis B: Enzymatic. 134: 32-36. https://doi.org/10.1016/j.molcatb.2016.09.011

Prasertsan, P., and Choorit, W. 1988. Problem solving on the occurrence of red waste water in seafood processing plant. Songklanakarin Journal Science Technological. 10: 439-446.

Qian, Z.L., Jung, W.K., and Kim, S.K. 2008. Free radical scavenging activity of a novel antioxidative peptide purified from hydrolysate of bullfrog skin, Rana catesbeiana Shaw. Bioresource Technology. 99: 1690-1698. https:// doi.org/10.1016/j.biortech.2007.04.005

Ritthibut, N. 2013. Purification, characterization, and stability of hatching enzyme from sailfin sandfish arctoscopus taponicus. Korea: GangneungWonju Nationnal University.

Sathivel, S., Bechtel, P., Babbitt, J., Smiley, S., Crapro, C., Reppond, K., and Prinyawiwatkul, W. 2003. Biochemical and functional properties of herring (Clupea harengus) by product hydrolysate. Journal of Food Science. 68: 2196-2200. https://doi.org/10.1111/j.1365-2621.2003.tb057 46.x 
Sukkwai, S., Kijroongrojana, K., and Benjakul, S. 2010. Extraction of gelatin from bigeye snapper (Priacanthus tayenus) skin for gelatin hydrolysate production. International of Food Research Journal. 18(3): 1129 - 1134.

Tanji, M., Kageyama, T., and Takahashi, K. 1988. Tuna pepsinogens and pepsins. Purification, characterization and amino-terminal sequences. European Journal of Biochemistry. 177(2): 256-259. https://doi.org/10.1111/j.14321033.1988.tb14369.x

Tanji, M., Yakabe, E., Kageyama, T., Yokobori, S., and Ichinose, M. 2007. purification and characterization of pepsinogens from the gastric mucosa of African coelacanth, Latimeria chalumnae, and properties of the major pepsins. Comparative Biochemistry and Physiology-Part B: Biochemistry and Molecular Biology. 146: 412-420. https://doi.org/10.1016/j.cbpb. 2006.11.025

Thai customs. 2019. Thai tuna statistics report of import and export in 2018. [accesses, 2019 Jan 18]. http://www.customs.go.th/statistic_report.php? ini_content=statistics_report\&lang=th\&left_menu=nmenu_esevice_007.

Thai Tuna Industry Association (TTIA). 2019. Thai tuna statistics of import and export in 2015-2017. [accesses Jan 18]. http://www.thaituna.org/home/ download/annual-report/Thai\%20Tuna\%20Statistics\%20of\%20Import\% 20\&\%20Export\%20in\%202015-2017.pdf.

Tohmadlea, P., Worawattanamateekul, W., and Hinsui, J. 2019. Tilapia gelatin: Elimination fishy odor. Rajamangala University of Technology Srivijaya Research Journal. 11(3): 1-9.

Venuste, M., Zhang, X., Shoemaker, C.F., Karangwa, E., Abbas, S., and Kamdem, P.E. 2013. Influence of enzymatic hydrolysis and enzyme type on the nutritional and antioxidant properties of pumpkin meal hydrolysates. Food Function. 4(5): 811-820. https://doi.org/10.1039/ c3f030347k

Worawattanamateekul, W. 2013. By-products of tuna processing: case studies from Thailand. Globe fish Research Program. 112: 36-48.

Wu, H.C., Chen, H.M., and Shiau, C.Y. 2003. Free amino acid and peptide as related to antioxidant properties in protein hydrolysate of mackerel (Scomber austriasicus). Food Research International. 36: 949-957. https:// doi.org/10.1016/s0963-9969(03)00104-2

Xu, R.A., Wong, R.J., Rogers, M. L., and Fletcher, G.C. 1996. Purification and characterization of acidic proteases from the stomach of the deep water finfish orange roughy (Hoplostethus atlanticus). Journal of Food Biochemistry. 20(6): 31-48. https://doi.org/10.1111/j.1745-4514.1996. tb00583.x

Zhoa L, Budge, S., Ghaly, A., Brooks, M., and Dave, D. 2011. Extraction, purification and characterization of fish pepsin. Journal of Food Processing Technology. 2(6): 1-14. https://doi.org/10.4172/2157-7110. 1000126 